\section{Review Article}

General Laboratory Medicine

Ann Lab Med 2021;41:549-558

https://doi.org/10.3343/alm.2021.41.6.549

ISSN 2234-3806 eISSN 2234-3814

\title{
Application of Single-Domain Antibodies ("Nanobodies") to Laboratory Diagnosis
}

\author{
Tahir S. Pillay (), MBChB., Ph.D. 1,2,3 and Serge Muyldermans (), Ph.D., ${ }^{4,5}$ \\ ${ }^{1}$ Department of Chemical Pathology and NHLS- Tshwane Academic Division, University of Pretoria, Pretoria, South Africa; ${ }^{2}$ Division of Chemical Pathology, \\ University of Cape Town, Cape Town, South Africa; ${ }^{3}$ Department of Chemical Pathology, University of Pretoria, Prinshof Campus, Pretoria, South Africa; \\ ${ }^{4}$ Cellular and Molecular Immunology, Vrije Universiteit Brussel, Brussels, Belgium; ${ }^{5}$ Liaoning Key Laboratory of Molecular Recognition and Imaging, School of \\ Bioengineering, Dalian University of Technology, Dalian, China
}

Antibodies have proven to be central in the development of diagnostic methods over decades, moving from polyclonal antibodies to the milestone development of monoclonal antibodies. Although monoclonal antibodies play a valuable role in diagnosis, their production is technically demanding and can be expensive. The large size of monoclonal antibodies (150 kDa) makes their re-engineering using recombinant methods a challenge. Single-domain antibodies, such as "nanobodies," are a relatively new class of diagnostic probes that originated serendipitously during the assay of camel serum. The immune system of the camelid family (camels, llamas, and alpacas) has evolved uniquely to produce heavy-chain antibodies that contain a single monomeric variable antibody domain in a smaller functional unit of $12-15 \mathrm{kDa}$. Interestingly, the same biological phenomenon is observed in sharks. Since a single-domain antibody molecule is smaller than a conventional mammalian antibody, recombinant engineering and protein expression in vitro using bacterial production systems are much simpler. The entire gene encoding such an antibody can be cloned and expressed in vitro. Single-domain antibodies are very stable and heat-resistant, and hence do not require cold storage, especially when incorporated into a diagnostic kit. Their simple genetic structure allows easy re-engineering of the protein to introduce new antigen-binding characteristics or attach labels. Here, we review the applications of single-domain antibodies in laboratory diagnosis and discuss the future potential in this area.

Key Words: Single-domain antibodies, Nanobodies, Monoclonal antibodies, Laboratory diagnosis
Received: January 4, 2021

Revision received: January 28, 2021

Accepted: May 24, 2021

\section{Corresponding author:}

Tahir S. Pillay, MBChB., Ph.D.

Department of Chemical Pathology,

University of Pretoria, Prinshof Campus,

Arcadia, Pretoria, 0007, South Africa

Tel: +27-12-319-2114

Fax: +27-12-328-3600

E-mail: tspillay@gmail.com

\section{IMMUNOASSAYS IN GENERAL}

Ligand binding assays are fundamental in laboratory medicine for measuring analytes and biomarkers. This class of assays exploits the binding reaction between an analyte or biomarker and a specific affinity reagent. In immunoassays, the affinity reagent is an antibody.

Immunoassays form the mainstay for protein biomarker measurements, and numerous proteins can be measured in healthy and diseased states. Some target proteins are abundantly present ( $>10 \mathrm{mg} / \mathrm{mL}$ ), whereas others are found at very low concentrations $(<1 \mathrm{pg} / \mathrm{mL})$ in clinical samples. The development of a suitable immunoassay depends on the availability of the protein antigen and the generation of an immune response in the host animal and the subsequent production of antibodies. Owing to the inherent diversity of an immune response and the structure and binding affinity of different antibodies for the same antigen, antibodies used in one assay or platform behave differ- 
ently from those used in another, unless they are the same clone of monoclonal antibody. There are numerous examples of variable results between different platforms for the same analyte, such as thyroid stimulating hormone and cancer antigen 19-9 $[1,2]$. Post-translational modifications of a protein analyte might be another factor that could affect reactivity with an antibody and lead to variable results. The challenges of using conventional antibodies in the laboratory have been outlined by Goodman [3].

However, there are many problems with immunoassays. In general, antibodies can originate from polyclonal or monoclonal sources. Although they are easy to produce, polyclonal antibodies are variable by nature, and there can be batch-to-batch variations in sera. Polyclonal antibodies have the advantage of being able to recognize multiple epitopes of a complex antigen, but inconsistency in production has hindered their use. The development of monoclonal antibodies was a milestone in the evolution of ligand-based assays. Monoclonal antibodies recognize a single epitope and can be produced in a pure and homogeneous form indefinitely from a hybridoma. Although monoclonal antibodies have a valuable role in diagnosis, their production is technically demanding and can be expensive. Moreover, the size of monoclonal antibodies (150 kDa) makes their re-engineering using recombinant methods a challenge. There is thus a need to develop new robust and reliable antibody probes for laboratory diagnosis. Conventional antibodies or complementary nucleic acid sequences represent the most common form of probes for the detection of various target molecules. Through the years, there have been attempts to reduce antibodies into fragments, either via enzymatic digestion methods (e.g., using pepsin or papain) or via recombinant engineering methods, such as those employing fragment antigen binding (Fab), single chain variable fragment (ScFv), and fragment variable (Fv) [4]. The discovery of naturally occurring heavy chain-only antibodies (HCAbs) in camelids heralded a new era in antibody engineering $[5,6]$.

\section{SINGLE-DOMAIN ANTIBODIES: GENERATION AND PROPERTIES}

The classical/canonical antibody in vertebrates contains two identical heavy and two identical light chains (Fig. 1). The immune system of camelids (camels, dromedaries, llamas, guanacos, vicuñas, and alpacas) has evolved uniquely to produce dimeric HCAb of approximately $90 \mathrm{kDa}$ that lack light chains and the $\mathrm{CH} 1$ domain (the first constant heavy chain domain) (Fig. 1). Among mammals, only members of the Camelidae family produce endogenous functional heavy-chain-only IgG. Interest-

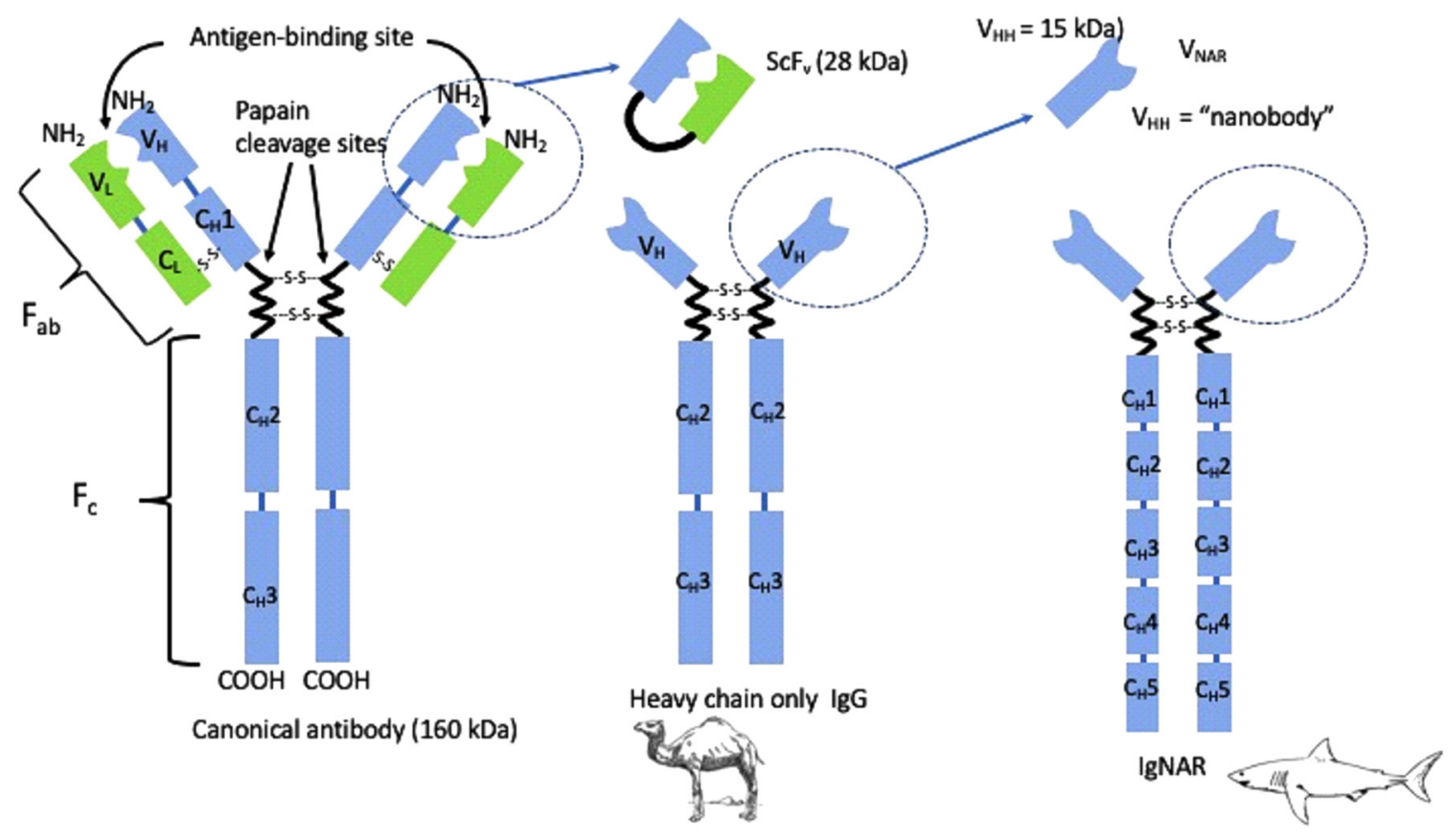

Fig. 1. Comparison of the canonical lg structure with that of heavy-chain-only antibodies.

Abbreviations: $\mathrm{V}_{\mathrm{HH}}$, variable heavy chain-only antibodies; $\mathrm{C}_{\mathrm{H}}$, constant region of heavy chain; $\mathrm{V}_{\mathrm{L}}$, variable region of light chain; $\mathrm{V}_{\mathrm{NAR}}$, variable domain of immunoglobulin new antigen receptor; Ig-NAR, immunoglobulin new antigen receptor; ScFv, single chain variable fragment. 
ingly, a similar biological phenomenon is observed in sharks [6, 7]. Cartilaginous fish, including nurse (Ginglymostoma cirratum), wobbegong (Orectolobus maculates), and dogfish (Squalus acanthias and Mustelus canis) sharks, also remarkably produce functional heavy-chain-only immunoglobulins (HClgs), named Ig new antigen receptor (IgNARs). The IgNAR of cartilaginous fish is also a homodimer of two heavy chains with one variable domain and five constant domains. In cartilaginous fish, the IgNARs account only for approximately $5 \%$ of total lgs. Various camelids express different proportions of HCAb, ranging from $50-75 \%$ in camels to approximately $20-40 \%$ in llama.

The serendipitous discovery of the natural occurrence of the unique, functional, homodimeric, $\mathrm{HClg}$ in camelid serum resulted from a laboratory course for graduate students at the Vrije Universiteit Brussels, Belgium [5]. Unlike the canonical mammalian antibody, $\mathrm{HClg}$ contains a single intact antigen-binding domain (variable domain of heavy chain of $\mathrm{HClg}, \mathrm{VHH}$ ). The counterpart to the $\mathrm{VHH}$ in cartilaginous fish is variable domain of IgNAR (V-NAR). This single-domain fragment contains only two hypervariable loop structures participating in antigen binding, whereas the VHH contains three hypervariable loops for antigen recognition. It has been postulated that the absence of the $\mathrm{CH} 1$ in these $\mathrm{HClgs}$ resulted from the loss of a splice consensus signal at the $5^{\prime}$ end of the " $\mathrm{CH} 1$-hinge" intron during evolution $[8,9]$. This altered splicing results in the joining of the $\mathrm{CH} 2$ domain of HCAb to the variable domain through a "hinge" region, which is unique to this class of antibodies [5].

There are two distinct types of hinges in the heavy chain-only IgG of camelids: the short hinge and the long hinge $[5,10]$. The $\mathrm{VHH}$ resembles conventional $\mathrm{VH}$ domains but is distinct in sequence and structure in that its sequence contains a few critical amino acid substitutions in the region that normally interacts with the variable light chain domain (VL) [5, 11-14]. These substitutions of large hydrophobic amino acids (in $\mathrm{VH}$ ) with smaller, hydrophilic amino acids (in $\mathrm{VHH}$ ) are responsible for the soluble behavior of the $\mathrm{VHH}$ and its function in the absence of a $\mathrm{VL}$ partner.

Thus, these variable antigen-binding domains $(\mathrm{VHH}$ and $\mathrm{V}$ NAR) are fully functional within a small 12-15 kDa unit [15]. The VHH contains approximately 120 amino acid residues, encoded by a gene of $360 \mathrm{bp}$. This gene can be cloned and subcloned easily. A protein size of approximately $13 \mathrm{kDa}$ is well within the limits of bacterial expression and is comparable with ScFv (25 kDa), Fab fragments (57 kDa), and the intact lgG (150 kDa).

$\mathrm{VHH}$ molecules form the basis to generate small, recombinant, autonomous single-domain antigen-binding fragments. The term "nanobody" was coined by the company Ablynx (Ghent, Belgium) in 2003 as a trademark, but it is now being generally used to describe small, recombinant, autonomous single-domain antigen-binding proteins, because of their small size (13 kDa; 2.5 $\mathrm{nm}$ in diameter and $4 \mathrm{~nm}$ in length). These nanobodies comprise a relatively new class of diagnostic probes. The patent on the use of fragments derived from the HCAb originally filed by Vrije Universiteit Brussel expired in 2014, resulting in increased interest in the commercialization of nanobodies [15].

The process of generating nanobodies begins with the immunization of a camelid. Following the development of an immune response, B-lymphocytes are isolated either from the peripheral blood or from lymph nodes and used to isolate mRNA. The mRNA is then used in reverse transcription to produce CDNA and perform $\mathrm{PCR}$ with $\mathrm{VHH}$-specific primers to amplify the $\mathrm{VHH}$ gene region, which is then cloned into a phage display expression vector to generate a library. Only primers for $\mathrm{VHH}$ are required, as opposed to the entire $\mathrm{HClg}$, because $\mathrm{VHH}$ alone contains the fully functional antigen-binding domain of the $\mathrm{HClg}$.

The process of animal immunization can also be bypassed through the construction of a naive or synthetic cDNA library. Thus, it is also possible to obtain VHHs from non-immune libraries [16], but immune libraries have greater diversity and usually yield VHHs with higher affinities [17]. Reactive VHHs that might bind weakly to the target can be modified by random or site-directed mutagenesis to isolate higher affinity binders.

Using the solid phase immobilized protein antigen (e.g., on magnetic beads), phage-expressing reactive nanobodies can be isolated through repeated cycles of screening and amplification in bacterial culture. Phage inserts can then be subcloned into bacterial or yeast expression vectors. The $\mathrm{VHH}$ gene can also be altered to a desired affinity and specificity by random mutagenesis or can be fused to a variety of short-peptide immunoassay tags (i.e., His6 [six histidine], c-myc [derived from the cmyc proto-oncogene], HA [derived from influenza hemagglutinin], Avi [biotin ligase target], ALFA [small $\alpha$-helix tag], and Ctag [4-amino acid peptide]) or various enzymes (horseradish peroxidase, alkaline phosphatase, or hemolysin). The nanobody construct can be produced ad infinitum in microbial cultures in the range of $\mathrm{mg}$ to $\mathrm{g} / \mathrm{L}$, a highly efficient yield for protein production. Target-recognizing nanobody clones can then be assayed for reactivity and utility in a variety of immunoassays, including sandwich or competitive ELISA, chemiluminescent enzyme immunoassay (CLEIA), bioluminescent enzyme immunoassay (BLEIA), lateral flow assay (LFA), and microfluidic and electrochemical devices for use in point-of-care testing, among others.

A typical nanobody has affinities (equilibrium dissociation con- 
stant) in the nanomolar to picomolar range, making them highly suited for application in ligand-binding assays [10]. They can bind to antigens with comparable affinity to that of conventional IgG, even though they lack the light chains that make up the antigen-binding region in IgG [18]. Since the functional part of the entire nanobody molecule is smaller than that of a conventional mammalian antibody, recombinant engineering and protein expression in vitro using bacterial production systems is much simpler using nanobodies. The entire nanobody gene can be cloned and expressed in vitro. It was later discovered in 1997 that nanobodies retain binding properties after long incubations (two weeks) at $37^{\circ} \mathrm{C}$ [19]. Moreover, these antibodies are very stable and heat-resistant at even higher temperatures, meaning that cold storage is not required, especially if these are incorporated into a diagnostic kit. Their resistance to $\mathrm{pH}$ extremes gives nanobodies the potential to be developed into oral drugs [20]. Furthermore, the simple structure of the genes encoding them allows re-engineering of the antigenic characteristics of nanobodies to "humanize" them for therapeutic applications. The following characteristics make nanobodies potentially useful for developing reagents for laboratory diagnosis:

Low cost of production: the small size of nanobodies enables easier production and high yields in moderate volumes of bacterial culture. Expression can be periplasmic or cytoplasmic. Periplasmic expression allows disulfide bridges to form and the purification of proteins from periplasmic extracts at yields of $1-20$ $\mathrm{mg} / \mathrm{L}$ on average [21]. Cytoplasmic expression produces much higher yields at 60-200 mg/L.

Easy tailoring to meet the application requirements (i.e., to improve specificity and affinity for broadening detection possibilities): the genes encoding nanobodies can be easily re-engineered to select for altered binding properties or epitope tagging for an immunoassay configuration. Single-domain antibodies bind to targets with comparable affinity to that of many conventional antibodies, sometimes with dissociation constants in the low picomolar range [22]. A myriad of methods is available to increase the affinity or avidity of any given nanobody. The availability of cDNA for a particular nanobody allows easy insertion of protein tags or labels using standard recombination methods.

Robustness and long shelf live: nanobodies are exceptionally heat stable in comparison with Igs and ScFv fragments and can thus be easily shipped at most ambient temperatures [18, 23]. Their melting temperatures $\left(\mathrm{T}_{\mathrm{m}}\right)$ can be as high as $80^{\circ} \mathrm{C}$, and some can be engineered to have a $\mathrm{T}_{\mathrm{m}}$ of even up to $90^{\circ} \mathrm{C}$. Some $\mathrm{VHHs}$, but not all, can refold and renature to $100 \%$ after denaturation.
Targeting cryptic or hidden epitopes: the small size of a nanobody allows it to enter antigen-binding sites in protein pockets and cavities that might not be accessible to conventional antibodies [24]. VHHs can bind to a variety of epitopes, from enzyme active sites [25, 26] to small molecules or haptens [27, 28].

Low immunogenicity [29, 30] and rapid blood clearance: the small size of a nanobody allows it to be freely filtered in the glomerulus, facilitating excretion. Therefore, for non-invasive in vivo imaging or therapeutic applications, if a nanobody is tagged with an anti-cancer molecule, residual toxicity will be minimized as the nanobody gets excreted. Nanobodies have low immunogenicity due to their sequence similarity with human IgG [31].

\section{THREE-DIMENSIONAL STRUCTURE OF NANOBODIES IN COMPLEX WITH ANTIGENS}

The average affinity of a nanobody for its antigen is approximately $6 \mathrm{nM}$, which is comparable with the affinity of the monomeric antigen-binding sites (Fab or $\mathrm{ScF}_{\mathrm{v}}$ ) of conventional antibodies for their antigens [32]. The structures of numerous nanobodies have been revealed by X-ray crystallography [32]. VHH contains an IgV fold with nine $\beta$-strands and a conserved disulfide bond between Cys23 and Cys104 (International ImMunoGeneTics [IMGT] information system numbering; Fig. 2). The V domain contains three hypervariable loops linked by four conserved framework regions. The paratopes on nanobodies are enriched with aromatic residues similar to conventional antibodies. The interactions between nanobodies and antigens are mediated by the three complementarity-determining region (CDR) loops and dominated by the CDR3 loop. The antigen epitopes tend to be more rigid and concave and are also enriched with aromatic residues. In contrast, conventional antibodies use six CDR loops (three in the variable domain of the heavy chain and three in the variable domain of the light chain) for antigen binding [32]. These structural insights are instrumental for the rational-design engineering of nanobodies into more potent affinity reagents [33].

\section{APPLICATION OF NANOBODIES AND ASSAY PERFORMANCE}

The question regarding which immunoassay applications benefit most from the substitution of classical antibodies with nanobodies remains. Nanobodies have been introduced in a wide variety of laboratory diagnostic techniques, mainly those for infectious diseases (Table 1). Considering their low cost of production and robust behavior (thermoresistance, long shelf life 

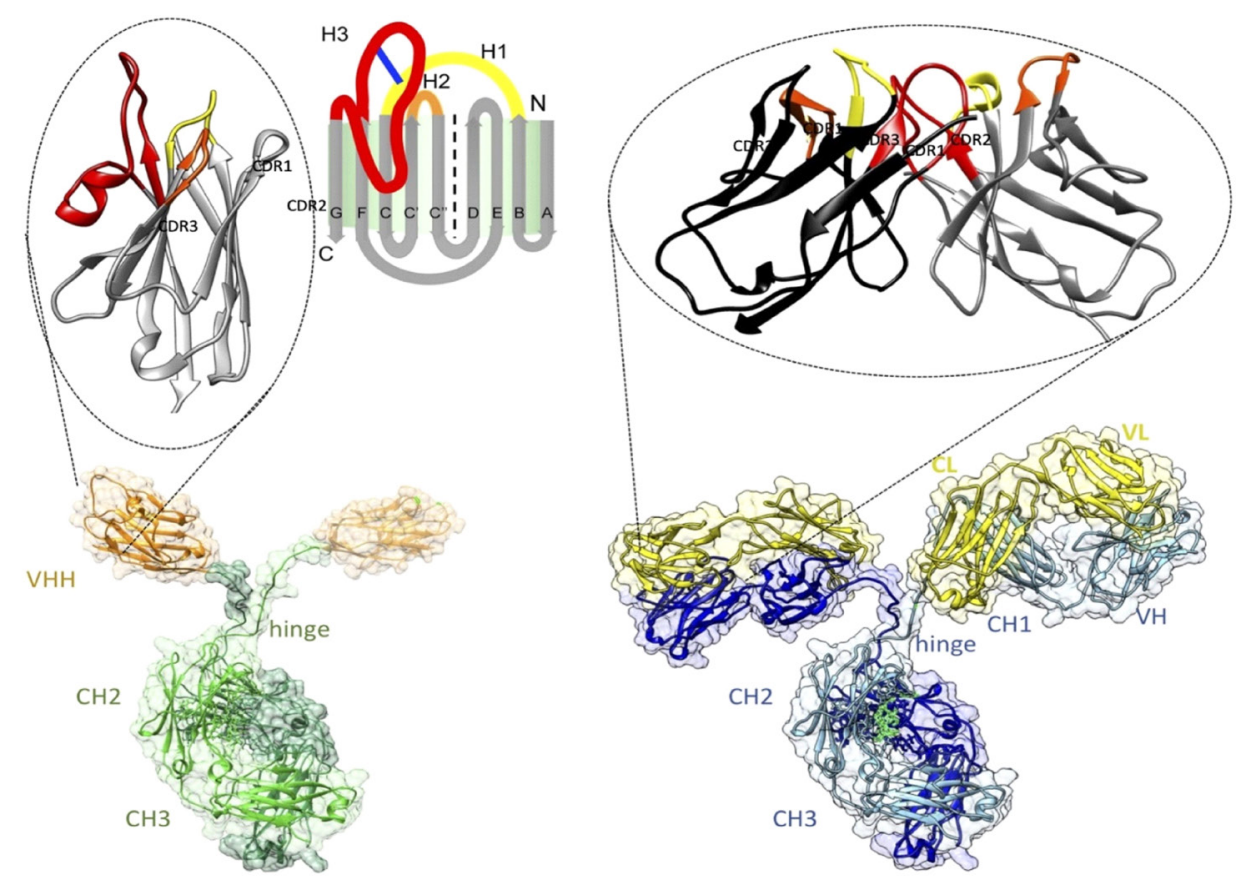

Fig. 2. Architectures of homodimeric heavy-chain antibodies (bottom left) with the Ag-binding single-domain VHH enlarged on top and classical heterotetrameric antibodies (bottom right) with the Ag-binding variable fragments (comprising VH and VL domains) enlarged on top. Adapted from Muyldermans (2021, ref 33). (Permission under Creative Commons Attribution license) (https://doi.org/10.1111/febs. 15515).

Abbreviations: $\mathrm{VHH}$, variable heavy chain-only antibodies; $\mathrm{CH}$, constant region of heavy chain; VL, variable region of light chain; $\mathrm{CDR}$, complementarity-determining region.

even in the absence of a cold chain), nanobodies are expected to become a preferred affinity reagent in future affordable LFAs. Nanobodies are perhaps less applicable for the "pregnancy test" type of applications but more applicable to assays that are used to monitor infectious diseases in animals (both farm and wild-life animals) living in remote areas. Efforts were made to monitor trypanosome and dengue fever using nanobodies [34, 35].The lack of applicability to techniques, such as a pregnancy/ HCG detection test, relates to the long-established footprint of conventional monoclonal antibody usage, and investment in HCG detection will make it difficult for nanobodies to replace monoclonal antibodies for these techniques.

In addition to LFAs, nanobodies have been assessed for the detection of various targets in ELISA-based methods. Although the generation of nanobodies against haptens is challenging, nanobodies against multiple small organic compounds have been identified [27, 36-39]. These nanobodies, combined with sensitive detection technologies or in competitive ELISA formats, appear to be a valuable tool for monitoring contaminants in soil or on food. For this, first, contaminating herbicides, fungicides, or insecticides must be extracted from soil or food. Many of these contaminants are hydrophobic and poorly soluble in aqueous solutions, and their extraction in dimethyl sulfoxide, methanol, acetone, and other organic solvents is not compatible with the proteinaceous probes. However, stable nanobodies appear to be resistant to exposure to such non-physiological solutes [4042].

The diagnostic sensitivities of LFAs and standard sandwich ELISA for particularly difficult-to-measure targets (i.e., glycosylated, biomarkers involved in variable assemblies or when present at extremely low concentrations), seem to be inadequate. In such cases, it might be necessary to switch to more sensitive detection methods, such as CLEIA or BLEIA, or more sophisticated new diagnostic instruments, such as (magneto-) electrochemical sensors [39, 43, 44]. The flexible format and small size of nanobodies allows for tailoring and adaptation for directional coupling at a high density on magnetic beads or on the sensor layer of novel biosensors [45, 46]. For example, the prostate specific antigen (PSA) sandwich immunosensor has a detection limit of $0.08 \mathrm{ng} / \mathrm{mL}$ and range of $0.1-100 \mathrm{ng} / \mathrm{mL}$ while the surface plasmon resonance assay for PSA has a detection limit of $0.3 \mathrm{ng} / \mathrm{mL}$, well below the clinical-detection lower limit of $4 \mathrm{ng} / \mathrm{mL}[45,46]$. This contrasts with the higher detection limits of various automated platforms using conventional antibodies 
Table 1. Selected examples of the use of nanobodies (and V-NAR) in disease diagnosis

\begin{tabular}{|c|c|c|c|}
\hline Antigen (target protein or small molecule) & Application & Method & Reference \\
\hline \multicolumn{4}{|l|}{ Detection of parasite or fungal infection } \\
\hline Malarial apical membrane antigen-1 & Plasmodium falciparum & Immunofluorescence (V-NAR) & [55] \\
\hline Trypanosomal pyruvate kinase & Trypanosoma congolense & ELISA and LFA & [35] \\
\hline Paraflagellar rod protein & $\begin{array}{l}\text { All trypanosome species (Trypanosoma evansi, } \\
\text { Trypanosoma congolense, Trypanosoma brucei, } \\
\text { Trypanosoma vivax) }\end{array}$ & ELISA and immunofluorescence & {$[56]$} \\
\hline Glycosomal aldolase & Trypanosoma congolense & ELISA & {$[57,58]$} \\
\hline $\begin{array}{l}\text { Iron superoxide dismutase } 1 \text {, tryparedoxin } 1 \text {, } \\
\text { nuclear transport factor } 2\end{array}$ & Leishmania infantum & ELISA & {$[59]$} \\
\hline Fasciola excretory secretory protein & Fasciola hepatica & ELISA & {$[60]$} \\
\hline Taenia solium 14 kDa diagnostic glycoprotein & Taenia solium & Sandwich ELISA & {$[61]$} \\
\hline Excretory secretory protein & Toxocara canis & $\begin{array}{l}\text { Sandwich ELISA and electrochemical } \\
\text { magnetosensor }\end{array}$ & {$[49,50,62]$} \\
\hline Alternaria mycotoxin tenuazonic acid & Alternaria & CLEIA and BLEIA & {$[63]$} \\
\hline \multicolumn{4}{|l|}{ Detection of bacterial infection } \\
\hline Chaperonin GroEL & Brucella & ELISA & {$[20]$} \\
\hline \multirow[t]{2}{*}{ Flagella } & Campylobacter jejuni or Campylobacter coli & Fluorescence microscopy/immunoblotting & {$[64,65]$} \\
\hline & Listeria monocytogenes & Sandwich ELISA & {$[66]$} \\
\hline Shiga toxin type 2 (B domain) & Shigella dysenteriae & Sandwich ELISA & {$[67]$} \\
\hline Cholera toxin & Vibrio cholerae & V-NAR Sandwich ELISA & {$[68]$} \\
\hline \multicolumn{4}{|l|}{ Detection of viral infection } \\
\hline Dengue virus type 2 NS1 protein & Dengue virus & LFA & {$[34]$} \\
\hline $\mathrm{H} 5 \mathrm{~N} 1$ & Influenza H5N1 & Double nanobody Sandwich ELISA & {$[69]$} \\
\hline E2/E3E2 envelope protein & Western equine encephalitis virus & Sandwich ELISA & {$[70]$} \\
\hline FMDV $3 A B C$ protein and synthetic peptides & Foot-and-mouth disease virus & Competitive ELISA & {$[71]$} \\
\hline PEDV N protein & Porcine epidemic diarrhea virus & Blocking ELISA & {$[72]$} \\
\hline Ebola virus nuclear protein & Zaire Ebola virus & V-NAR ELISA & [73] \\
\hline \multicolumn{4}{|l|}{ Detection of small toxic molecules } \\
\hline Caffeine & Caffeine contamination & Competitive ELISA & {$[27]$} \\
\hline Biphenyl 2,3-dioxygenase & Oil refinery waste treatment & Western blot & {$[36]$} \\
\hline Parathion & Organophosphorous pesticide detection & $\begin{array}{l}\text { One-step direct competitive fluorescent } \\
\text { immunoassay }\end{array}$ & {$[37]$} \\
\hline 3-Phenoxybenzoic acid & Detection of pyrethroid insecticides in urine & $\begin{array}{l}\text { One-step direct competitive fluorescent } \\
\text { immunoassay }\end{array}$ & [38] \\
\hline Tetrabromobisphenol & Flame retardant & Competitive ELISA & {$[40]$} \\
\hline Dicamba & Contamination with selective herbicide & CLEIA & {$[39]$} \\
\hline \multicolumn{4}{|l|}{ Detection of human disease or malignancy } \\
\hline Human glycophorin A (CD235a) & Anti-HIV-1 p24 antibodies & $\begin{array}{l}\text { Anti-CD235a VHH fused to HIV-1 p24- } \\
\text { agglutination for HIV diagnosis }\end{array}$ & {$[74]$} \\
\hline Alpha-fetoprotein & Cancer biomarker & ELISA and immuno-PCR & [75] \\
\hline $\begin{array}{l}\text { Pancreatic secretory zymogen-granule } \\
\text { glycoprotein } 2\end{array}$ & Crohn's disease & ELISA and immunohistochemistry & {$[76]$} \\
\hline CEA & Cancer biomarker & Biosensor for cancer biomarker & [44] \\
\hline
\end{tabular}


Table 1. Continued

\begin{tabular}{lllc}
\hline Antigen (target protein or small molecule) & \multicolumn{1}{c}{ Application } & Method & Reference \\
\hline Procalcitonin & Serum marker for bacterial infections & Electrochemiluminescence & {$[43]$} \\
Growth hormone & Anti-doping assay & Sandwich ELISA & {$[48]$} \\
CD22 & B-cell malignancies/leukemia & ELISA and FACS & {$[77]$} \\
hPSA & Prostate cancer & Sandwich ELISA/Surface plasma & {$[45,46]$} \\
& & resonance-based assay & {$[78]$} \\
CD38 & Soluble CD38 in multiple myeloma & Sandwich assay & {$[79]$} \\
Human $\beta$-2-microglobulin & Amyloid disease & Fluorescence immunostaining & \\
In vivo non-invasive imaging & & & {$[80]$} \\
EGFR & Tumor solid burden & SPECT/microCT & {$[81]$} \\
CD33 & Acute myeloid leukemia & Non-invasive imaging (PET/SPECT) & {$[54]$} \\
HER2 & Breast cancer & & {$[82,83]$} \\
MMR & Tumor-associated macrophages & SPECT/microCT and PET & {$[84]$} \\
PSMA & Prostate cancer & SPECT/microCT & {$[85,86]$} \\
CD20 & Non-Hodgkin lymphoma & Theranostic & {$[87]$} \\
DPP6 & Pancreatic endocrine cells & SPECT/CT & {$[88]$} \\
CA IX & Hypoxic ductal carcinoma & Molecular fluorescence imaging & {$[89]$} \\
Clec4F and Vsig4 & Kupffer cells, acute hepatitis, staging of liver & Immunohistochemistry and SPECT & {$[90,91]$} \\
CRlg & pathogenesis & & {$[92]$} \\
VCAM1 & Rheumatoid arthritis/joint inflammation & SPECT/CT & {$[93]$} \\
Fibronectin & Atherosclerotic lesions & SPECT imaging & PET/CT \\
\hline
\end{tabular}

Abbreviations: LFA, lateral flow assay; SPECT, single-photon emission computed tomography; CT, computed tomography; CLEIA, chemiluminescence enzyme immunoassay; BLEIA, bioluminescent enzyme immunoassay; MMR, macrophage mannose receptor; V-NAR, variable domain of immunoglobulin new antigen receptor. PEDV, porcine epidemic diarrhea virus; FMDV, foot-and-mouth disease virus; VHH, variable heavy chain-only antibodies (also known as single-domain antibodies); HIV, human immunodeficiency virus; PCR, polymerase chain reaction; FACS, fluorescent activated cell sorting; hPSA, human prostate specific antigen; EGFR, epidermal growth factor receptor; PET, positron emission tomography; CA IX, carbonic anhydrase 9; PSMA, prostate-specific membrane antigen; NS1, non-structural protein 1.

[47]. Similar advantages in sensitivity were seen with a growth hormone assay utilizing a nanobody, wherein a detection range of $0.5-110 \mathrm{ng} / \mathrm{mL}$ was achieved [48]. Our efforts to design better performing assays culminated in a recent highly reproducible sensitive and specific assay for Toxocara excretory secretory components $[49,50]$.

\section{CONCLUSIONS}

Although many efforts have been undertaken in academic institutions to introduce nanobodies in standard ELISAs to monitor biomarkers for human health (Table 1), it will be extremely difficult to substitute the well-established classical monoclonal antibodies in these applications (refer to the HCG test example). Nevertheless, there might be one notable exception, specifically in vivo non-invasive imaging [51]. The small size of monomeric nanobodies allows them to rapidly extravasate from veins and diffuse evenly into tissues to reach their targets. At the same time, excess nanobodies are rapidly cleared from the blood via the kidneys. Hence, radionuclide-labeled nanobodies injected intravenously distribute throughout the body, whereas kidney clearance removes excess free nanobody, with a minor fraction accumulating at the diseased sites in the body, based on the specificity of the nanobody. If extended half-life is desired to improve imaging, a nanobody can be coupled to other proteins $[52,53]$. The lesions or spots of diseased, infected, or inflamed tissue will be loaded with labeled nanobodies that can be monitored via PET or single-photon emission computed tomography whole body scans. This highly promising non-invasive imaging technique has been used in mouse studies with nanobodies against cancer biomarkers and for sites of inflammation (Table 1). A phase I study has been reported for anti-HER2 nanobodies in breast cancer patients [54]. As illustrated in this review, increasing future applications of nanobodies for diagnostic pur- 
poses are likely in the clinical laboratory, particularly in the context of infectious disease, as well as for imaging.

\section{AUTHOR CONTRIBUTIONS}

Pillay TS conceived the idea for the review article and produced the first draft. Muyldermans S reviewed and modified the first draft extensively for the final submission.

\section{CONFLICTS OF INTEREST}

None declared

\section{RESEARCH FUNDING}

Funding was provided by the National Research Foundation, South Africa.

\section{ORCID}

Tahir Pillay https://orcid.org/0000-0002-9982-9710

Serge Muyldermans https://orcid.org/0000-0002-3678-3575

\section{REFERENCES}

1. Rawlins ML and Roberts WL. Performance characteristics of six thirdgeneration assays for thyroid-stimulating hormone. Clin Chem 2004;50: 2338-44.

2. La'ulu SL and Roberts WL. Performance characteristics of five automated CA 19-9 assays. Am J Clin Pathol 2007;127:436-40.

3. Goodman SL. The antibody horror show: an introductory guide for the perplexed. N Biotechnol 2018;45:9-13.

4. O'Kennedy R and Roben P. Antibody engineering: an overview. Essays Biochem 1991;26:59-75.

5. Hamers-Casterman C, Atarhouch T, Muyldermans S, Robinson G, Hamers $\mathrm{C}$, Songa $\mathrm{EB}$, et al. Naturally occurring antibodies devoid of light chains. Nature 1993:363:446-8.

6. Greenberg AS, Avila D, Hughes M, Hughes A, McKinney EC, Flajnik MF. A new antigen receptor gene family that undergoes rearrangement and extensive somatic diversification in sharks. Nature 1995;374:168-73.

7. Roux KH, Greenberg AS, Greene L, Strelets L, Avila D, McKinney EC, et al. Structural analysis of the nurse shark (new) antigen receptor (NAR): molecular convergence of NAR and unusual mammalian immunoglobulins. Proc Natl Acad Sci U S A 1998;95:11804-9.

8. Nguyen VK, Hamers R, Wyns L, Muyldermans S. Loss of splice consensus signal is responsible for the removal of the entire $\mathrm{C}(\mathrm{H}) 1$ domain of the functional camel IGG2A heavy-chain antibodies. Mol Immunol 1999; 36:515-24.

9. Woolven BP, Frenken LG, van der Logt P, Nicholls PJ. The structure of the llama heavy chain constant genes reveals a mechanism for heavychain antibody formation. Immunogenetics 1999;50:98-101.

10. van der Linden R, de Geus B, Stok W, Bos W, van Wassenaar D, Verrips
T, et al. Induction of immune responses and molecular cloning of the heavy chain antibody repertoire of Lama glama. J Immunol Methods 2000;240:185-95.

11. Vu KB, Ghahroudi MA, Wyns L, Muyldermans S. Comparison of llama $\mathrm{VH}$ sequences from conventional and heavy chain antibodies. Mol Immunol 1997;34:1121-31.

12. Harmsen MM, Ruuls RC, Nijman IJ, Niewold TA, Frenken LG, de Geus B. Llama heavy-chain $V$ regions consist of at least four distinct subfamilies revealing novel sequence features. Mol Immunol 2000;37:579-90.

13. Decanniere K, Muyldermans S, Wyns L. Canonical antigen-binding loop structures in immunoglobulins: more structures, more canonical classes? J Mol Biol 2000;300:83-91.

14. Muyldermans S, Atarhouch T, Saldanha J, Barbosa JA, Hamers R. Sequence and structure of $\mathrm{VH}$ domain from naturally occurring camel heavy chain immunoglobulins lacking light chains. Protein Eng 1994;7:112935.

15. Muyldermans S. Nanobodies: natural single-domain antibodies. Annu Rev Biochem 2013;82:775-97.

16. Verheesen P, Roussis A, de Haard HJ, Groot AJ, Stam JC, den Dunnen JT, et al. Reliable and controllable antibody fragment selections from Camelid non-immune libraries for target validation. Biochim Biophys Acta 2006:1764:1307-19.

17. Nguyen VK, Desmyter A, Muyldermans S. Functional heavy-chain antibodies in Camelidae. Adv Immunol 2001;79:261-96.

18. van der Linden RH, Frenken LG, de Geus B, Harmsen MM, Ruuls RC, Stok W, et al. Comparison of physical chemical properties of llama $\mathrm{VHH}$ antibody fragments and mouse monoclonal antibodies. Biochim Biophys Acta 1999;1431:37-46.

19. Arbabi Ghahroudi M, Desmyter A, Wyns L, Hamers R, Muyldermans S. Selection and identification of single domain antibody fragments from camel heavy-chain antibodies. FEBS Lett 1997;414:521-6.

20. Abbady AQ, Al-Daoude A, Al-Mariri A, Zarkawi M, Muyldermans S. Chaperonin GroEL a Brucella immunodominant antigen identified using Nanobody and MALDI-TOF-MS technologies. Vet Immunol Immunopathol 2012;146:254-63.

21. Saerens D, Stijlemans B, Baral TN, Nguyen Thi GT, Wernery U, Magez S, et al. Parallel selection of multiple anti-infectome Nanobodies without access to purified antigens. J Immunol Methods 2008;329:138-50.

22. Sockolosky JT, Dougan M, Ingram JR, Ho CC, Kauke MJ, Almo SC, et al. Durable antitumor responses to CD47 blockade require adaptive immune stimulation. Proc Natl Acad Sci U S A 2016;113:E2646-54.

23. Dumoulin M, Conrath K, Van Meirhaeghe A, Meersman F, Heremans K, Frenken LG, et al. Single-domain antibody fragments with high conformational stability. Protein Sci 2002;11:500-15.

24. Lauwereys M, Arbabi Ghahroudi M, Desmyter A, Kinne J, Hölzer W, De Genst $\mathrm{E}$, et al. Potent enzyme inhibitors derived from dromedary heavychain antibodies. EMBO J 1998;17:3512-20.

25. Desmyter A, Decanniere K, Muyldermans S, Wyns L. Antigen specificity and high affinity binding provided by one single loop of a camel singledomain antibody. J Biol Chem 2001;276:26285-90.

26. Desmyter A, Transue TR, Ghahroudi MA, Thi MH, Poortmans F, Hamers R, et al. Crystal structure of a camel single-domain VH antibody fragment in complex with lysozyme. Nat Struct Biol 1996;3:803-11.

27. Ladenson RC, Crimmins DL, Landt Y, Ladenson JH. Isolation and characterization of a thermally stable recombinant anti-caffeine heavy-chain antibody fragment. Anal Chem 2006;78:4501-8.

28. Spinelli S, Frenken LG, Hermans P, Verrips T, Brown K, Tegoni M, et al. Camelid heavy-chain variable domains provide efficient combining sites to haptens. Biochemistry 2000;39:1217-22.

29. Kijanka M, Dorresteijn B, Oliveira S, van Bergen en Henegouwen PM. 
Nanobody-based cancer therapy of solid tumors. Nanomedicine (Lond) 2015;10:161-74.

30. Vincke C, Loris R, Saerens D, Martinez-Rodriguez S, Muyldermans S, Conrath K. General strategy to humanize a camelid single-domain antibody and identification of a universal humanized nanobody scaffold. J Biol Chem 2009;284:3273-84.

31. Klarenbeek A, El Mazouari K, Desmyter A, Blanchetot C, Hultberg A, de Jonge $\mathrm{N}$, et al. Camelid Ig $\mathrm{V}$ genes reveal significant human homology not seen in therapeutic target genes, providing for a powerful therapeutic antibody platform. MAbs 2015;7:693-706.

32. Zavrtanik U, Lukan J, Loris R, Lah J, Hadži S. Structural basis of epitope recognition by heavy-chain camelid antibodies. J Mol Biol 2018;430: 4369-86.

33. Muyldermans S. A guide to: generation and design of nanobodies. FEBS J 2021;288:2084-102.

34. Fatima A, Wang H, Kang K, Xia L, Wang Y, Ye W, et al. Development of $\mathrm{VHH}$ antibodies against dengue virus type 2 NS1 and comparison with monoclonal antibodies for use in immunological diagnosis. PLoS One 2014;9:e95263.

35. Pinto Torres JE, Goossens J, Ding J, Li Z, Lu S, Vertommen D, et al. Development of a nanobody-based lateral flow assay to detect active Trypanosoma congolense infections. Sci Rep 2018;8:9019.

36. Fraile S, Jiménez JI, Gutiérrez C, de Lorenzo V. NanoPad: an integrated platform for bacterial production of camel nanobodies aimed at detecting environmental biomarkers. Proteomics 2013;13:2766-75.

37. Zhang YQ, Xu ZL, Wang F, Cai J, Dong JX, Zhang JR, et al. Isolation of Bactrian camel single domain antibody for parathion and development of one-step dc-FEIA method using VHH-alkaline phosphatase fusion protein. Anal Chem 2018;90:12886-92.

38. Huo J, Li Z, Wan D, Li D, Qi M, Barnych B, et al. Development of a highly sensitive direct competitive fluorescence enzyme immunoassay based on a nanobody-alkaline phosphatase fusion protein for detection of 3-phenoxybenzoic acid in urine. J Agric Food Chem 2018;66:11284-90.

39. Huo J, Barnych B, Li Z, Wan D, Li D, Vasylieva N, et al. Hapten synthesis, antibody development, and a highly sensitive indirect competitive chemiluminescent enzyme immunoassay for detection of dicamba. J Agric Food Chem 2019;67:5711-9.

40. Kim HJ, McCoy MR, Majkova Z, Dechant JE, Gee SJ, Tabares-da Rosa S, et al. Isolation of alpaca anti-hapten heavy chain single domain antibodies for development of sensitive immunoassay. Anal Chem 2012;84: 1165-71.

41. Wang J, Bever CR, Majkova Z, Dechant JE, Yang J, Gee SJ, et al. Heterologous antigen selection of camelid heavy chain single domain antibodies against tetrabromobisphenol A. Anal Chem 2014;86:8296-302.

42. Zhang JR, Wang Y, Dong JX, Yang JY, Zhang YQ, Wang F, et al. Development of a simple pretreatment immunoassay based on an organic solvent-tolerant nanobody for the detection of carbofuran in vegetable and fruit samples. Biomolecules 2019;9:576.

43. Li H, Sun Y, Elseviers J, Muyldermans S, Liu S, Wan Y. A nanobody-based electrochemiluminescent immunosensor for sensitive detection of human procalcitonin. Analyst 2014;139:3718-21.

44. Liu JL, Raghu D, Anderson GP, Goldman ER, Christodoulides JA, Raphael MP. Improving biosensing activity to carcinoembryonic antigen with orientated single domain antibodies. Heliyon 2017;3:e00478.

45. Saerens D, Frederix F, Reekmans G, Conrath K, Jans K, Brys L, et al. Engineering camel single-domain antibodies and immobilization chemistry for human prostate-specific antigen sensing. Anal Chem 2005;77: 7547-55.

46. Liu X, Wang D, Chu J, Xu Y, Wang W. Sandwich pair nanobodies, a potential tool for electrochemical immunosensing serum prostate-specific antigen with preferable specificity. J Pharm Biomed Anal 2018;158: 361-9.

47. Bock JL and Klee GG. How sensitive is a prostate-specific antigen measurement? How sensitive does it need to be? Arch Pathol Lab Med 2004; 128:341-3.

48. Murad H, Assaad JM, Al-Shemali R, Abbady AQ. Exploiting nanobodies in the detection and quantification of human growth hormone via phagesandwich enzyme-linked immunosorbent assay. Front Endocrinol (Lausanne) 2017;8:115.

49. Morales-Yánez F, Trashin S, Hermy M, Sariego I, Polman K, Muyldermans $\mathrm{S}$, et al. Fast one-step ultrasensitive detection of Toxocara canis antigens by a nanobody-based electrochemical magnetosensor. Anal Chem 2019;91:11582-8.

50. Morales-Yánez F, Trashin S, Sariego I, Roucher C, Paredis L, Chico M, et al. Electrochemical detection of Toxocara canis excretory-secretory antigens in children from rural communities in Esmeraldas Province, Ecuador: association between active infection and high eosinophilia. Parasit Vectors 2020;13:245.

51. Vaneycken I, D'Huyvetter M, Hernot S, De Vos J, Xavier C, Devoogdt N, et al. Immuno-imaging using nanobodies. Curr Opin Biotechnol 2011; 22:877-81.

52. Hutt M, Färber-Schwarz A, Unverdorben F, Richter F, Kontermann RE. Plasma half-life extension of small recombinant antibodies by fusion to immunoglobulin-binding domains. J Biol Chem 2012;287:4462-9.

53. Unverdorben F, Färber-Schwarz A, Richter F, Hutt M, Kontermann RE. Half-life extension of a single-chain diabody by fusion to domain $B$ of staphylococcal protein A. Protein Eng Des Sel 2012;25:81-8.

54. Keyaerts M, Xavier C, Heemskerk J, Devoogdt N, Everaert H, Ackaert C, et al. Phase I study of 68Ga-HER2-nanobody for PET/CT assessment of HER2 expression in breast carcinoma. J Nucl Med 2016;57:27-33.

55. Nuttall SD, Humberstone KS, Krishnan UV, Carmichael JA, Doughty L, Hattarki M, et al. Selection and affinity maturation of IgNAR variable domains targeting Plasmodium falciparum AMA1. Proteins 2004;55:18797.

56. Obishakin E, Stijlemans B, Santi-Rocca J, Vandenberghe I, Devreese B, Muldermans S, et al. Generation of a nanobody targeting the paraflagellar rod protein of trypanosomes. PLoS One 2014;9:e115893.

57. Odongo S, Sterckx YG, Stijlemans B, Pillay D, Baltz T, Muyldermans S, et al. An anti-proteome nanobody library approach yields a specific immunoassay for Trypanosoma congolense diagnosis targeting glycosomal aldolase. PLoS Negl Trop Dis 2016;10:e0004420.

58. Pinto J, Odongo S, Lee F, Gaspariunaite V, Muyldermans S, Magez S, et al. Structural basis for the high specificity of a Trypanosoma congolense immunoassay targeting glycosomal aldolase. PLoS Negl Trop Dis 2017; 11:e0005932.

59. Abeijon C, Dilo J, Tremblay JM, Viana AG, Bueno LL, Carvalho SFG, et al. Use of $\mathrm{VHH}$ antibodies for the development of antigen detection test for visceral leishmaniasis. Parasite Immunol 2018;40:e12584.

60. Barreto T, Alfonso Y, Lafaye P, García Lazaro MDP, Agueda Perez L, Herrera-Velit $\mathrm{P}$, et al. Single-chain antibodies from alpaca for the detection of Fasciola hepatica antigens. Rev Peru Med Exp Salud Publica 2018; 35:573-80

61. Deckers N, Saerens D, Kanobana K, Conrath K, Victor B, Wernery U, et al. Nanobodies, a promising tool for species-specific diagnosis of Taenia solium cysticercosis. Int J Parasitol 2009;39:625-33.

62. Morales-Yanez FJ, Sariego I, Vincke C, Hassanzadeh-Ghassabeh G, Polman K, Muyldermans S. An innovative approach in the detection of Toxocara canis excretory/secretory antigens using specific nanobodies. Int J Parasitol 2019;49:635-45.

63. Wang F, Li ZF, Yang YY, Wan DB, Vasylieva N, Zhang YQ, et al. Chemi- 
luminescent enzyme immunoassay and bioluminescent enzyme immunoassay for tenuazonic acid mycotoxin by exploitation of nanobody and nanobody-nanoluciferase fusion. Anal Chem 2020;92:11935-42.

64. Riazi A, Strong PC, Coleman R, Chen W, Hirama T, van Faassen H, et al. Pentavalent single-domain antibodies reduce Campylobacter jejuni motility and colonization in chickens. PLoS One 2013;8:e83928.

65. Hussack G, Riazi A, Ryan S, van Faassen H, MacKenzie R, Tanha J, et al. Protease-resistant single-domain antibodies inhibit Campylobacter jejuni motility. Protein Eng Des Sel 2014;27:191-8.

66. Tu Z, Chen Q, Li Y, Xiong Y, Xu Y, Hu N, et al. Identification and characterization of species-specific nanobodies for the detection of Listeria monocytogenes in milk. Anal Biochem 2016;493:1-7.

67. Melli LJ, Zylberman V, Hiriart Y, Lauche CE, Baschkier A, Pardo R, et al. Development and evaluation of a novel $\mathrm{VHH}$-based immunocapture assay for high-sensitivity detection of Shiga toxin Type 2 (Stx2) in stool samples. J Clin Microbiol 2020;58:e01566-19.

68. Liu JL, Anderson GP, Delehanty JB, Baumann R, Hayhurst A, Goldman ER. Selection of cholera toxin specific IgNAR single-domain antibodies from a naïve shark library. Mol Immunol 2007;44:1775-83.

69. Zhu M, Gong X, Hu Y, Ou W, Wan Y. Streptavidin-biotin-based directional double Nanobody sandwich ELISA for clinical rapid and sensitive detection of influenza H5N1. J Transl Med 2014;12:352.

70. Liu JL, Shriver-Lake LC, Zabetakis D, Goldman ER, Anderson GP. Selection of single-domain antibodies towards western equine encephalitis virus. Antibodies (Basel) 2018;7:44.

71. Gelkop S, Sobarzo A, Brangel P, Vincke C, Romão E, Fedida-Metula S, et al. The development and validation of a novel nanobody-based competitive ELISA for the detection of foot and mouth disease 3ABC antibodies in cattle. Front Vet Sci 2018;5:250.

72. Ma Z, Wang T, Li Z, Guo X, Tian Y, Li Y, et al. A novel biotinylated nanobody-based blocking ELISA for the rapid and sensitive clinical detection of porcine epidemic diarrhea virus. J Nanobiotechnology 2019;17:96.

73. Goodchild SA, Dooley H, Schoepp RJ, Flajnik M, Lonsdale SG. Isolation and characterisation of Ebolavirus-specific recombinant antibody fragments from murine and shark immune libraries. Mol Immunol 2011; 48:2027-37.

74. Habib I, Smolarek D, Hattab C, Grodecka M, Hassanzadeh-Ghassabeh G, Muyldermans S, et al. V(H)H (nanobody) directed against human glycophorin A: a tool for autologous red cell agglutination assays. Anal Biochem 2013;438:82-9.

75. Chen J, He QH, Xu Y, Fu JH, Li YP, Tu Z, et al. Nanobody medicated immunoassay for ultrasensitive detection of cancer biomarker alpha-fetoprotein. Talanta 2016;147:523-30.

76. Schlör A, Holzlöhner P, Listek M, Griess C, Butze M, Micheel B, et al. Generation and validation of murine monoclonal and camelid recombinant single domain antibodies specific for human pancreatic glycoprotein 2. N Biotechnol 2018;45:60-8.

77. Faraji F, Tajik N, Behdani M, Shokrgozar MA, Zarnani AH, Shahhosseini $F$, et al. Development and characterization of a camelid single-domain antibody directed to human CD22 biomarker. Biotechnol Appl Biochem 2018;65:718-25.

78. Li T, Li SL, Fang C, Hou YN, Zhang Q, Du X, et al. Nanobody-based dual epitopes protein identification (DepID) assay for measuring soluble CD38 in plasma of multiple myeloma patients. Anal Chim Acta 2018;1029: 65-71.
79. Huang C, Li D, Ren J, Ji F, Jia L. Generation and application of fluorescent anti-human beta2-microglobulin VHH's via amino modification. Molecules 2019;24:2600.

80. Gainkam LO, Keyaerts M, Caveliers V, Devoogdt N, Vanhove C, Van Grunsven L, et al. Correlation between epidermal growth factor receptor-specific nanobody uptake and tumor burden: a tool for noninvasive monitoring of tumor response to therapy. Mol Imaging Biol 2011;13:940-8.

81. Romão E, Krasniqi A, Maes L, Vandenbrande C, Sterckx YG, Stijlemans $B$, et al. Identification of nanobodies against the acute myeloid leukemia marker CD33. Int J Mol Sci 2020;21:310.

82. Movahedi K, Schoonooghe S, Laoui D, Houbracken I, Waelput W, Breckpot $\mathrm{K}$, et al. Nanobody-based targeting of the macrophage mannose receptor for effective in vivo imaging of tumor-associated macrophages. Cancer Res 2012;72:4165-77.

83. Blykers A, Schoonooghe S, Xavier C, D'Hoe K, Laoui D, D'Huyvetter M, et al. PET imaging of macrophage mannose receptor-expressing macrophages in tumor stroma using 18F-Radiolabeled camelid single-domain antibody fragments. J Nucl Med 2015;56:1265-71.

84. Evazalipour M, D'Huyvetter M, Tehrani BS, Abolhassani M, Omidfar K, Abdoli S, et al. Generation and characterization of nanobodies targeting PSMA for molecular imaging of prostate cancer. Contrast Media Mol Imaging 2014;9:211-20.

85. Krasniqi A, D'Huyvetter M, Xavier C, Van der Jeught K, Muyldermans S, Van Der Heyden J, et al. Theranostic radiolabeled anti-CD20 sdAb for targeted radionuclide therapy of non-Hodgkin lymphoma. Mol Cancer Ther 2017;16:2828-39.

86. Krasniqi A, Bialkowska M, Xavier C, Van der Jeught K, Muyldermans S, Devoogdt N, et al. Pharmacokinetics of radiolabeled dimeric sdAbs constructs targeting human CD20. N Biotechnol 2018;45:69-79.

87. Balhuizen A, Massa S, Mathijs I, Turatsinze JV, De Vos J, Demine S, et al. A nanobody-based tracer targeting DPP6 for non-invasive imaging of human pancreatic endocrine cells. Sci Rep 2017;7:15130.

88. van Brussel AS, Adams A, Vermeulen JF, Oliveira S, van der Wall E, Mali WP, et al. Molecular imaging with a fluorescent antibody targeting carbonic anhydrase IX can successfully detect hypoxic ductal carcinoma in situ of the breast. Breast Cancer Res Treat 2013;140:263-72.

89. Zheng F, Sparkes A, De Baetselier P, Schoonooghe S, Stijlemans B, Muyldermans $\mathrm{S}$, et al. Molecular imaging with Kupffer cell-targeting nanobodies for diagnosis and prognosis in mouse models of liver pathogenesis. Mol Imaging Biol 2017; 19:49-58.

90. Zheng F, Perlman H, Matthys P, Wen Y, Lahoutte T, Muyldermans S, et al. Specificity evaluation and disease monitoring in arthritis imaging with complement receptor of the Ig superfamily targeting Nanobodies. Sci Rep 2016;6:35966.

91. Zheng F, Put S, Bouwens L, Lahoutte T, Matthys P, Muyldermans S, et al. Molecular imaging with macrophage CRIg-targeting nanobodies for early and preclinical diagnosis in a mouse model of rheumatoid arthritis. J Nucl Med 2014;55:824-9.

92. Broisat A, Hernot S, Toczek J, De Vos J, Riou LM, Martin S, et al. Nanobodies targeting mouse/human VCAM1 for the nuclear imaging of atherosclerotic lesions. Circ Res 2012;110:927-37.

93. Jailkhani N, Ingram JR, Rashidian M, Rickelt S, Tian C, Mak H, et al. Noninvasive imaging of tumor progression, metastasis, and fibrosis using a nanobody targeting the extracellular matrix. Proc Natl Acad Sci U S A 2019;116:14181-90. 